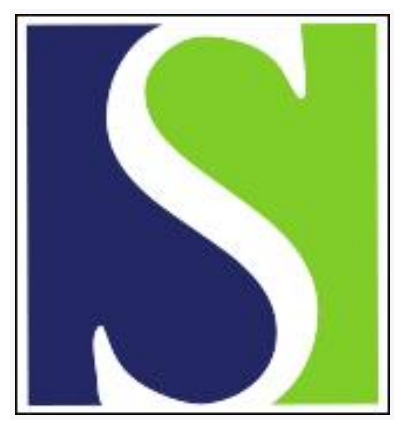

Scand J Work Environ Health 2008;34(6):411-419

https://doi.org/10.5271/sjweh.1290

Issue date: 00 Dec 2008

Occupational loading, health behavior and sleep disturbance as predictors of low-back pain

by Miranda $H$, Viikari-Juntura $E$, Punnett L, Riihimäki H

Affiliation: Finnish Institute of Occupational Health, Topeliuksenkatu 41 a A, 00250 Helsinki, Finland. Helena.Miranda@ttl.fi

Refers to the following texts of the Journal: 2006;32(4):294-299

2003;29(6):431-440 1996;22(4):251-259 2003;29(6):444-451

The following articles refer to this text: 2009;35(3):193-202;

2009;35(4):301-308

Key terms: age; health behavior; lifestyle; low-back pain; musculoskeletal pain; occupational loading; physical work; predictor; risk factor; sleep disturbance

This article in PubMed: www.ncbi.nlm.nih.gov/pubmed/19137202 


\title{
Occupational loading, health behavior and sleep disturbance as predictors of low-back pain
}

\author{
by Helena Miranda, MD, ${ }^{1}$ Eira Viikari-Juntura, MD, ${ }^{1}$ Laura Punnett, ScD, ${ }^{2}$ Hilkka Riihimäki, MD ${ }^{1}$
}

\begin{abstract}
Miranda H, Viikari-Juntura E, Punnett L, Riihimäki H. Occupational loading, health behavior and sleep disturbance as predictors of low-back pain. Scand J Work Environ Health 2008;34(6):411-419.

Objectives Risk factors for low-back pain are known to co-occur, but their joint effect has not often been studied. Little is also known about the variation of the risk factors or their effects with age.

Methods This prospective study assessed the 1-year incidence of low-back pain by age group in a Finnish industrial population. The effects of the baseline variables on the risk of low-back pain in the follow-up were estimated with a log-binomial regression.

Results Among 2256 blue- and white-collar workers free of low-back pain 12 months preceding the baseline, $21 \%$ reported low-back pain after 1-year of follow-up. Physical work load (sum of heavy lifting, awkward postures, and whole-body vibration) predicted low-back pain among those younger than 50 years [highest relative risk (RR) 2.4, 95\% confidence interval (95\% CI) 1.4-4.2], whereas health behavior (sum of smoking, overweight, and lack of physical exercise) increased the risk only among those 50 years or older (RR up to $2.8,95 \% \mathrm{CI}$ 1.4-5.4). Mental stress, dissatisfaction with life, and sleep problems were significant predictors in the group of 40- to 49-year-old workers. Work-related psychosocial factors were not associated with the outcome.

Conclusions In this study, workers of different ages were affected by slightly different risk factors. The results support the provision of health promotion and stress management as part of programs to prevent work-related low-back pain. In particular, aging workers may benefit from such an integrated approach. More prospective studies on the joint effects of age-specific risk factors of low-back pain are warranted.
\end{abstract}

Key terms age; lifestyle; musculoskeletal pain; physical work; risk factor.

Low-back pain is a major global occupational and public health burden. It affects millions of workers every year worldwide, causing frequent medical visits, sickness absence, disability, and early retirement $(1,2)$. It has been estimated that $60-70 \%$ of people in industrialized countries experience low-back pain at some point in their lives (1). In reality, the lifetime prevalence may be closer to $100 \%$ in that it is known that a considerable percentage of people, in some studies $30-40 \%$ or even higher, forget their prior symptoms (3-5).

Work-related physical exposures, especially heavy lifting and manual materials handling, awkward postures, and whole-body vibration, are well-established risk factors for low-back pain $(6,7)$. Some psychosocial factors have also been linked to low-back pain in earlier studies, but the results have been somewhat inconsistent $(7,8)$. Personal health factors, such as smoking, overweight, and lack of physical activity, are often listed among the most important risk factors for low-back pain, but the scientific evidence is surprisingly vague and inconsistent (9-14).

The independent effects of the risk factors for multifactorial conditions such as low-back pain may be difficult to assess due to their accumulation in the same persons (15-17). It can be debated whether it is meaningful to assess the separate effects only, as is often done in occupational epidemiology, knowing that exposures co-occur and may also act synergistically $(18,19)$. For example, in industrial populations, workers are rarely exposed to whole-body vibration alone, without being affected by awkward work postures or lifting. Similarly, overweight and smoking have both been found to be associated with a physically inactive lifestyle. The joint effects of multiple physical workload factors and health behavior have not often been studied, however, in relation to low-back pain. In addition, little is known about the extent to which these effects vary by age. Thus the aim of this prospective study in an industrial population

1 Centre of Expertise for Health and Work Ability, Finnish Institute of Occupational Health, Helsinki, Finland.

2 Department of Work Environment, University of Massachusetts Lowell, Lowell, Massachusetts, United States.

Correspondence to: Dr H Miranda, Finnish Institute of Occupational Health, Topeliuksenkatu 41 a A, 00250 Helsinki, Finland. [E-mail: Helena.Miranda@ttl.fi] 
was to assess the 1-year incidence of low-back pain and its risk factors by age group.

\section{Study population and methods}

This study is a part of a larger network of projects in the Finnish Institute of Occupational Health called MUSKELI (preventing musculoskeletal diseases in industry). The project was approved by the Ethics Committee of the Finnish Institute of Occupational Health. In 1992, all employees of a large company in the Finnish forest industry received a questionnaire on musculoskeletal pain and its potential risk factors. The self-administered questionnaire was sent by the occupational health service of the company. The 7000 employees consisted of all workers in mechanical and chemical forest industry processes and their maintenance tasks, as well as foremen, laboratory staff, technical designers, office clerks, and management. After two reminders, $75 \%$ filled out and returned the questionnaire. Part-time workers and a small number of employees with rheumatoid arthritis were excluded from the study, leaving 5180 workers in the baseline study population. A follow-up questionnaire was sent after 1 year (in 1993), to which 4283 workers $(83 \%)$ responded. Information on low-back pain at baseline or follow-up was available for 3873 workers. Altogether $74 \%$ of the study participants were men.

\section{Outcome}

The outcome of this study was the 1-year incidence of a new episode of low-back pain. The questions on lowback pain both at the baseline and the follow-up were based on a Nordic questionnaire asking the workers to estimate the number of days with low-back pain during the preceding 12 months (20). To assess the incidence at follow-up, those with low-back pain at the baseline (reported having pain for more than 7 days during the preceding 12 months) were excluded from the analyses $(\mathrm{N}=1617)$, leaving a baseline population of 2256 workers with no low-back pain (or for only a few days). Cases of low-back pain were those who reported low-back pain ( $>7$ days) at the follow-up, and the reference group was formed from those who had no low-back pain (0-7 days) at the follow-up.

\section{Predictors}

The baseline questionnaire contained several questions on work-related physical and psychosocial exposures, individual demographics, health, health behavior, sleep, and psychological factors. The following separate items assessed physical workload on the back in the current job during an average workday: heavy lifting (exposed, if the worker reported lifting loads of $>25 \mathrm{~kg}$ ), working with the trunk in awkward postures (exposed, if working with the trunk flexed forward for $>2$ hours, twisting the trunk moderately or much, or working with a twisted neck for $>1$ hour), or whole-body vibration (exposed for $>4$ hours) (21). The number of exposures was used to represent the total physical loading at work, varying from none to all three being present.

The perceived risk of acute injury ("accidents") at work due to tripping, slipping, or climbing stairs was formed by summing four separate items that were designed for this study (eg, "How much do you estimate moving on slippery surfaces, for example, ice or oil, to increase the risk of accidents in your own work?", 1=not at all to 4=much; cut-off from median, ie, 1). The questionnaire contained one question about skill discretion ("Are you able to use your skills and knowledge in your work?", 1=very much to 5=very little) and one question about decision authority ("Do you have the possibility to influence the issues related to your work?", 1=very much to $5=$ not at all). These variables were summed to form a job-control variable (sum scale 2-10). The questionnaire also included two questions on psychological demands at work, which were also summed ("Do you need to hurry to get your work done?", $1=$ never to $5=$ all the time; "Does your work have phases that are too difficult?", $1=$ never to $5=$ all the time). The demand questions were from the Occupational Stress Questionnaire (22). The combination of low job control (lower than the median of the study population, ie, 5) and high work demands (higher than the median, ie, 5) was classified as high job strain and was compared with low job strain (either high control or low demands or both). Supervisory and coworker support were also assessed with one item each ("Do you get support from your supervisor if needed?", $1=$ very much to $5=$ =very little; "What kind of relationship do you have with your coworkers?", $1=$ very good to $5=$ =very poor), as well as job satisfaction ("Are you satisfied with your work?") and satisfaction with life ("Are you satisfied with your life?").

The following three aspects of health behavior were assessed: body mass index (classified as $0=\leq 24.9,1=$ $25.0-29.9,2=\geq 30.0 \mathrm{~kg} / \mathrm{m}^{2}$ ), physical exercise (eg, bicycling, swimming, etc, weekly during the preceding year, at least 20 minutes per session, classified as $0=$ average of $\geq 2-3$ times/week; $1=1$ time/week; $2=$ not at all or $<1$ time/week), and smoking ( $0=$ never smoked, $1=$ former smoker, $2=$ current smoker). To form a composite variable, the values were summed and classified into three categories of $0,1-3$, and $4-6$ ( 0 being the reference class, representing a normal-weight, never smoking, and actively exercising worker).

Sleep disturbance was considered to be mild if the workers reported either not sleeping well during the preceding 3 months or having been extremely tired after 
waking up most of the mornings in a week and to be severe if they had reported both (23). Mental distress was based on questions about being stressed, nervous, or tense, and it was classified into three categories (no, somewhat, or much or very much) (24). The workers were asked if they had any chronic illnesses (eg, diabetes) that required medical treatment or follow-up. Information on pain in other areas of the musculoskeletal system (neck, shoulder, upper extremities, hip or knee) at baseline was obtained with questions similar those used for low-back pain.

\section{Data analyses}

The main aim of the study was to assess the predictors among the younger ( $<40$ years), middle-age (40-49 years), and older ( $\geq 50$ years) workers. These cut-offs were chosen on the basis of practicality (to provide easily interpretable categories), as well as on the age distribution of the population. Log-binomial regression with the PROC GENMOD procedure was used to estimate the relative risks (RR) and their $95 \%$ confidence intervals (95\% CI) (25).

Gender- and age-adjusted associations (age as a continuous variable within the age strata) were computed for the variables of main interest (ie, physical exposures and health risk behavior). Each multivariable model included all of the covariates that were statistically significant $(\mathrm{P}<0.05)$ in any of the age groups. This stage of modeling consisted of 1676 workers with no missing values for any exposure. The chronic disease items contained the most missing values, but no selection based on the outcome occurred among those who were excluded from the analyses due to missing values. However, additional analyses were performed by imputing the value "having chronic disease", as well as the value "not having chronic disease", separately for all of workers with a missing value for chronic diseases. The statistical analyses were carried out with the statistical software package SAS (version 9.1, SAS Institute Inc, Cary, NC, USA).

\section{Results}

Altogether 29\% of the participants worked in "whitecollar" occupations, and $71 \%$ worked in "blue-collar" jobs. Of the blue-collar workers, most (85\%) worked in industrial paper manufacturing, whereas $15 \%$ worked in forest lumbering, the heaviest form of work in this industry. The distributions of the occupational groups were similar in the three age groups, except that the percentage of lumbermen was lowest in the oldest group (9\% compared with $12 \%$ in the two younger age groups).
The nonrespondents at follow-up did not differ from the respondents with respect to low-back or any other musculoskeletal pain or exposures to physical work, health risk behavior, or the other baseline variables used as predictors in this study. With regard to the initial participation at baseline, the younger and male workers participated slightly less than the older and female workers, but the differences were small. Because of confidentiality regulations we were not able to collect any other data from the nonrespondents at baseline after their refusal to participate.

Of all the workers who, at baseline, had not experienced low-back pain during the preceding 12 months, $21 \%$ developed low-back pain during the 1-year follow-up. The incidence of low-back pain was somewhat higher for the participants over 50 years of age, among both the men and the women. Nine out of ten workers with a new episode of low-back pain reported experiencing considerable problems in daily activities due to low-back pain, and, for most (58\%) of these workers, these problems had lasted for more than a week.

The crude associations between the exposures and low-back pain incidence are shown in table 1 . In the log-binomial analyses (table 2), exposure to heavy lifting and whole-body vibration was associated with the incidence of low-back pain among the youngest workers, awkward postures and whole-body vibration (latter with borderline significance) were associated with low-back pain in the middle-age group, and whole-body vibration was associated with low-back pain among the oldest workers. The younger workers exposed to three physical risk factors had an increased risk of low-back pain (RR $2.4,95 \%$ CI $1.4-4.2$ in the final multivariable model) (table 3). In the group of 40- to 49-year-old workers, the risk increased with just one physical exposure present. Tests for trend were statistically significant for these age groups. In the oldest age group, the total physical workload did not increase the risk of low-back pain significantly.

Smoking, overweight, and a lack of physical exercise predicted future low-back pain (BMI and exercise with borderline significance) in the gender- and age-adjusted models for the older workers, whereas no effect was found for the middle-age group. Among the youngest workers, only obesity was associated with low-back pain. The set of three aspects of health behavior had a relative risk of 2.8 (95\% CI 1.4-5.4) for the older workers $(\mathrm{P}=0.0018$ for trend), but it did not predict low-back pain in either of the younger age groups.

Psychological factors (ie, mental distress and life satisfaction) as well as the quality of sleep, were predictors of future low-back pain among the 40- to 49-yearold workers (table 3 ). These factors did not increase the risk significantly among the other groups, except sleep disturbance, which predicted low-back pain among the 
Table 1. One-year incidence of low-back pain among forest industry workers in Finland, according to age group and baseline exposure.

\begin{tabular}{|c|c|c|c|c|c|c|c|c|c|}
\hline & \multicolumn{9}{|c|}{ Incidence of low-back pain } \\
\hline & \multicolumn{3}{|c|}{$<40$-year-old group } & \multicolumn{3}{|c|}{ 40- to 49-year-old group } & \multicolumn{3}{|c|}{$\geq 50$-year-old group } \\
\hline & \multirow{2}{*}{$\begin{array}{l}\text { All (N) } \\
N\end{array}$} & \multicolumn{2}{|c|}{ Cases } & \multirow{2}{*}{$\begin{array}{c}\text { All (N) } \\
\%\end{array}$} & \multicolumn{2}{|c|}{ Cases } & \multirow[t]{2}{*}{ All (N) } & \multicolumn{2}{|c|}{ Cases } \\
\hline & & $\mathrm{N}$ & $\%$ & & $\mathrm{~N}$ & $\%$ & & $\mathrm{~N}$ & $\%$ \\
\hline All participants & 948 & 165 & 17 & 826 & 178 & 22 & 482 & 482 & 28 \\
\hline \multicolumn{10}{|l|}{ Gender } \\
\hline Male & 724 & 126 & 17 & 596 & 129 & 22 & 358 & 98 & 27 \\
\hline Female & 224 & 39 & 17 & 230 & 49 & 21 & 124 & 36 & 29 \\
\hline \multicolumn{10}{|l|}{ Physical workload factors } \\
\hline Work involving heavy I & & & & & & & & & \\
\hline No & 599 & 95 & 16 & 588 & 124 & 21 & 373 & 105 & 28 \\
\hline Yes & 311 & 62 & 20 & 211 & 49 & 23 & 85 & 22 & 26 \\
\hline Working with awkward & cunk post & & & & & & & & \\
\hline No & 400 & 62 & 16 & 360 & 64 & 18 & 206 & 58 & 28 \\
\hline Yes & 544 & 102 & 19 & 457 & 114 & 25 & 265 & 75 & 28 \\
\hline Exposed to whole-bod & jibration & & & & & & & & \\
\hline No & 803 & 123 & 15 & 707 & 151 & 21 & 414 & 111 & 27 \\
\hline Yes & 141 & 42 & 30 & 106 & 25 & 24 & 59 & 20 & 34 \\
\hline Number of physical ex & sures $(\mathrm{h}$ & ting, a & $\operatorname{vard} p$ & whole-b & ibration) & & & & \\
\hline 0 & 305 & 43 & 14 & 304 & 53 & 17 & 180 & 46 & 26 \\
\hline 1 & 310 & 51 & 16 & 275 & 70 & 25 & 165 & 55 & 33 \\
\hline 2 & 230 & 44 & 19 & 156 & 34 & 22 & 80 & 18 & 23 \\
\hline 3 & 60 & 18 & 30 & 49 & 14 & 29 & 19 & 6 & 32 \\
\hline Health risk behavior & & & & & & & & & \\
\hline Smoking & & & & & & & & & \\
\hline Never smoker & 414 & 68 & 16 & 337 & 68 & 20 & 249 & 59 & 24 \\
\hline Ex-smoker & 226 & 40 & 18 & 250 & 61 & 24 & 155 & 51 & 33 \\
\hline Current smoker & 305 & 56 & 18 & 234 & 47 & 20 & 77 & 24 & 31 \\
\hline Body mass index $(\mathrm{kg} / \mathrm{n}$ & & & & & & & & & \\
\hline$\leq 24.9$ & 613 & 96 & 16 & 372 & 81 & 22 & 195 & 47 & 24 \\
\hline $25.0-29.9$ & 286 & 56 & 20 & 346 & 75 & 22 & 237 & 73 & 31 \\
\hline$\geq 30.0$ & 42 & 12 & 29 & 92 & 21 & 23 & 43 & 13 & 30 \\
\hline Physical exercise & & & & & & & & & \\
\hline$\geq 2-3$ times/week & 613 & 107 & 17 & 528 & 113 & 21 & 317 & 80 & 25 \\
\hline 1 time/week & 203 & 30 & 15 & 157 & 39 & 25 & 90 & 30 & 33 \\
\hline $0-<1$ time/week & 125 & 28 & 22 & 136 & 25 & 18 & 68 & 21 & 31 \\
\hline Health risk behavior ( 0 & rweight, & exerci & and sr & $m$ index & & & & & \\
\hline 0 & 187 & 32 & 17 & 135 & 28 & 21 & 90 & 15 & 17 \\
\hline $1-3$ & 642 & 106 & 17 & 526 & 114 & 22 & 313 & 92 & 29 \\
\hline $4-6$ & 102 & 25 & 25 & 139 & 32 & 23 & 64 & 23 & 36 \\
\hline Other factors & & & & & & & & & \\
\hline Sleeping disturbance & & & & & & & & & \\
\hline No & 558 & 85 & 15 & 431 & 64 & 15 & 202 & 33 & 16 \\
\hline Mild & 335 & 68 & 20 & 363 & 99 & 27 & 252 & 92 & 37 \\
\hline Severe & 54 & 12 & 22 & 30 & 15 & 50 & 26 & 9 & 35 \\
\hline Mental distress (being & ressed, $\mathrm{r}$ & or ten & & & & & & & \\
\hline No & 420 & 60 & 14 & 357 & 51 & 14 & 199 & 39 & 20 \\
\hline Somewhat & 416 & 82 & 20 & 384 & 101 & 26 & 225 & 67 & 30 \\
\hline Much or very much & 106 & 22 & 21 & 82 & 26 & 32 & 54 & 27 & 50 \\
\hline Satisfaction with life & & & & & & & & & \\
\hline Satisfied & 804 & 138 & 17 & 700 & 138 & 20 & 393 & 111 & 28 \\
\hline Not satisfied & 141 & 27 & 19 & 124 & 39 & 31 & 87 & 23 & 26 \\
\hline Chronic diseases & & & & & & & & & \\
\hline No & 715 & 114 & 16 & 554 & 106 & 19 & 258 & 58 & 22 \\
\hline Yes & 102 & 32 & 31 & 153 & 35 & 23 & 150 & 51 & 34 \\
\hline Pain in other areas (ne & upper e & ties, hi & knee & & & & & & \\
\hline No & 433 & 56 & 13 & 331 & 47 & 14 & 168 & 31 & 18 \\
\hline Yes & 464 & 102 & 22 & 425 & 114 & 27 & 278 & 94 & 34 \\
\hline Job strain (high demar & s-low co & & & & & & & & \\
\hline No & 796 & 134 & 17 & 671 & 144 & 21 & 383 & 99 & 26 \\
\hline Yes & 147 & 30 & 20 & 150 & 33 & 22 & 94 & 33 & 35 \\
\hline Risk of accidents & & & & & & & & & \\
\hline No & 474 & 79 & 17 & 507 & 104 & 21 & 332 & 90 & 27 \\
\hline Yes & 468 & 85 & 18 & 300 & 70 & 23 & 141 & 39 & 28 \\
\hline
\end{tabular}


Table 2. Adjusted relative risks of the effects of the physical exposures and the risk factors for health risk behavior on the 1-year incidence of low-back pain among the forest industry workers in Finland, according to age group. (RR = relative risk, $95 \% \mathrm{Cl}=95 \% \mathrm{confidence}$ interval)

\begin{tabular}{|c|c|c|c|c|c|c|c|c|c|c|c|c|}
\hline \multirow[t]{4}{*}{ Baseline variables } & \multicolumn{12}{|c|}{ Incidence of low-back pain } \\
\hline & \multicolumn{4}{|c|}{$<40$-year-old group } & \multicolumn{4}{|c|}{ 40- to 49-year-old group } & \multicolumn{4}{|c|}{$\geq 50$-year-old group } \\
\hline & \multicolumn{2}{|c|}{ Model 1a ${ }^{a}$} & \multicolumn{2}{|c|}{ Model 1 $b^{b}$} & \multicolumn{2}{|c|}{ Model 2a a } & \multicolumn{2}{|c|}{ Model 2b b } & \multicolumn{2}{|c|}{ Model 3a ${ }^{a}$} & \multicolumn{2}{|c|}{ Model 3b ${ }^{b}$} \\
\hline & $\mathrm{RR}$ & $95 \% \mathrm{Cl}$ & $\mathrm{RR}$ & $95 \% \mathrm{Cl}$ & RR & $95 \% \mathrm{Cl}$ & $\mathrm{RR}$ & $95 \% \mathrm{Cl}$ & $\mathrm{RR}$ & $95 \% \mathrm{Cl}$ & RR & $95 \% \mathrm{Cl}$ \\
\hline \multicolumn{13}{|l|}{ Heavy lifting } \\
\hline No & 1.0 &.. & 1.0 &.. & 1.0 &.. & 1.0 & .. & 1.0 &.. & 1.0 & .. \\
\hline Yes & 1.5 & $1.1-2.1$ & 1.4 & $1.0-2.1$ & 1.1 & $0.8-1.6$ & 1.0 & $0.7-1.4$ & 1.0 & $0.6-1.6$ & 0.9 & $0.6-1.5$ \\
\hline \multicolumn{13}{|l|}{ Awkward postures } \\
\hline No & 1.0 &.. & 1.0 &.. & 1.0 &.. & 1.0 &.. & 1.0 &.. & 1.0 &.. \\
\hline Yes & 1.2 & $0.8-1.6$ & 0.9 & $0.7-1.3$ & 1.6 & $1.2-2.3$ & 1.6 & $1.1-2.3$ & 0.9 & $0.7-1.3$ & 0.8 & $0.6-1.2$ \\
\hline \multicolumn{13}{|l|}{ Whole-body vibration } \\
\hline No & 1.0 &.. & 1.0 & .. & 1.0 &.. & 1.0 & .. & 1.0 &.. & 1.0 &.. \\
\hline Yes & 2.0 & $1.4-2.9$ & 1.9 & $1.3-2.9$ & 1.5 & $1.0-2.2$ & 1.2 & $0.8-1.8$ & 1.7 & $1.1-2.6$ & 1.8 & $1.1-3.0$ \\
\hline \multicolumn{13}{|l|}{ Smoking } \\
\hline Never smoker & 1.0 &.. & 1.0 &.. & 1.0 & .. & 1.0 & .. & 1.0 &.. & 1.0 & .. \\
\hline Ex-smoker & 1.0 & $0.7-1.5$ & 1.0 & $0.7-1.4$ & 1.3 & $0.9-1.8$ & 1.2 & $0.9-1.8$ & 1.7 & $1.1-2.5$ & 1.6 & $1.1-2.2$ \\
\hline Current smoker & 1.0 & $0.7-1.5$ & 1.0 & $0.7-1.4$ & 1.1 & $0.8-1.7$ & 1.0 & $0.7-1.7$ & 1.6 & $1.0-2.7$ & 1.4 & $0.9-2.4$ \\
\hline \multicolumn{13}{|c|}{ Body mass index $\left(\mathrm{kg} / \mathrm{m}^{2}\right)$} \\
\hline$\leq 24.9$ & 1.0 &.. & 1.0 &.. & 1.0 &.. & 1.0 & .. & 1.0 &.. & 1.0 & .. \\
\hline $25.0-29.9$ & 1.1 & $0.8-1.6$ & 1.0 & $0.7-1.4$ & 1.0 & $0.7-1.4$ & 1.0 & $0.7-1.4$ & 1.4 & $1.0-2.1$ & 1.3 & $0.9-1.9$ \\
\hline$\geq 30.0$ & 1.8 & $1.0-3.2$ & 1.9 & $1.1-3.3$ & 1.2 & $0.7-1.9$ & 1.1 & $0.7-1.8$ & 1.3 & $0.7-2.4$ & 1.2 & $0.6-2.2$ \\
\hline \multicolumn{13}{|l|}{ Physical exercise } \\
\hline$\geq 2-3$ times/week & 1.0 &.$\cdot$ & 1.0 &.$\cdot$ & 1.0 &.$\cdot$ & 1.0 & $\cdot \cdot$ & 1.0 &.$\cdot$ & 1.0 & $\cdot$. \\
\hline 1 time/week & 0.9 & $0.6-1.3$ & 0.8 & $0.5-1.2$ & 1.0 & $0.7-1.6$ & 1.1 & $0.7-1.6$ & 1.1 & $0.7-1.8$ & 1.1 & $0.7-1.7$ \\
\hline $0-<1$ time/week & 1.1 & $0.7-1.7$ & 1.0 & $0.7-1.5$ & 0.9 & $0.6-1.5$ & 0.9 & $0.6-1.5$ & 1.5 & $1.0-2.4$ & 1.4 & $0.9-2.1$ \\
\hline
\end{tabular}

a Models 1a-3a adjusted for gender and age.

${ }^{b}$ Models $1 \mathrm{~b}-3 \mathrm{~b}$ adjusted for all of the variables in the table, and also gender and age.

oldest workers. Moreover, although, at the baseline, the workers were free of low-back pain, many had reported pain in other anatomical areas (neck pain the most frequently). Pain in other areas predicted future low-back pain in all of the age groups, but it retained its statistical significance in the multivariable models only in the youngest age group. The presence of a chronic disease was a significant predictor only in this age group as well. Work-related psychosocial factors (job strain, supervisory or coworker support, or job satisfaction), education, and perceived risk of "accident" at work were not associated with the outcome. Since we detected differences in the risk factors and their effects when the analyses were stratified by age, we also tested the interactions between age and physical workload and health behavior in the whole cohort. These interactions did not reach statistical significance when the standard P-value was 0.05

\section{Discussion}

In this moderately large and heterogeneous group of industrial workers, every fifth worker developed a new episode of low-back pain during the 1-year follow-up. This finding is similar to or somewhat higher than those reported in other occupational studies (26-28). The differences in the definition of low-back pain partly explain the discrepancies across studies. For instance, in a study by Van Nieuwenhuyse et al (28), the 1-year incidence of low-back pain was $13 \%$, a value that is markedly lower than in our study, but the authors required a case of low-back pain to have $\geq 7$ consecutive pain days during the preceding 12 months (28). We did not collect information on low-back pain severity other than the extent of resulting problems in daily living, which was considerable for nearly all of the workers who had new pain during the follow-up. This finding indicates that the outcome of our study had an important impact on the lives of these workers.

The occupational physical risk factors for low-back pain (ie, awkward postures, heavy lifting, and wholebody vibration) were, as expected, significant predictors, but not uniformly across the age groups. Whole-body vibration had a relatively strong association with lowback pain among the youngest and oldest workers. Vibration may induce low-back pain via several pathophysiological mechanisms, including increased trunk 
Table 3. Adjusted relative risks of the effects of the predictors of the 1-year incidence of low-back pain among the forest industry workers in Finland, according to age group. ( $\mathrm{RR}=$ relative risk, $95 \% \mathrm{Cl}==95 \%$ confidence interval)

\begin{tabular}{|c|c|c|c|c|c|c|c|c|c|c|c|c|}
\hline \multirow[t]{4}{*}{ Baseline variables } & \multicolumn{12}{|c|}{ Incidence of low-back pain } \\
\hline & \multicolumn{4}{|c|}{$<40$-year-old group } & \multicolumn{4}{|c|}{ 40- to 49-year-old group } & \multicolumn{4}{|c|}{$\geq 50$-year-old group } \\
\hline & \multicolumn{2}{|c|}{ Model 1a ${ }^{a}$} & \multicolumn{2}{|c|}{ Model 1 $b^{b}$} & \multicolumn{2}{|c|}{ Model 2a $\mathrm{a}^{\mathrm{a}}$} & \multicolumn{2}{|c|}{ Model 2b ${ }^{b}$} & \multicolumn{2}{|c|}{ Model $3 a^{a}$} & \multicolumn{2}{|c|}{ Model 3b ${ }^{b}$} \\
\hline & $\mathrm{RR}$ & $95 \% \mathrm{Cl}$ & $\mathrm{RR}$ & $95 \% \mathrm{Cl}$ & $\mathrm{RR}$ & $95 \% \mathrm{Cl}$ & $\mathrm{RR}$ & $95 \% \mathrm{Cl}$ & $\mathrm{RR}$ & $95 \% \mathrm{Cl}$ & $\mathrm{RR}$ & $95 \% \mathrm{Cl}$ \\
\hline \multicolumn{13}{|c|}{ Number of physical exposures (heavy lifting, awkward postures of the trunk, and whole-body vibration) } \\
\hline $\begin{array}{l}0 \\
1 \\
2 \\
3\end{array}$ & $\begin{array}{l}1.0 \\
1.0 \\
1.3 \\
2.5\end{array}$ & $\begin{array}{c}. . \\
0.7-1.6 \\
0.9-2.0 \\
1.5-4.2\end{array}$ & $\begin{array}{l}1.0 \\
1.0 \\
1.3 \\
2.4\end{array}$ & $\begin{array}{c}. . \\
0.7-1.5 \\
0.8-1.9 \\
1.4-4.2\end{array}$ & $\begin{array}{l}1.0 \\
1.7 \\
1.4 \\
2.3\end{array}$ & $\begin{array}{c}. . \\
1.2-2.6 \\
0.9-2.3 \\
1.3-4.1\end{array}$ & $\begin{array}{l}1.0 \\
1.6 \\
1.5 \\
2.1\end{array}$ & $\begin{array}{c}. . \\
1.1-2.4 \\
0.9-2.4 \\
1.2-3.9\end{array}$ & $\begin{array}{l}1.0 \\
1.1 \\
1.0 \\
1.4\end{array}$ & $\begin{array}{c}. . \\
0.7-1.6 \\
0.6-1.7 \\
0.7-2.9\end{array}$ & $\begin{array}{l}1.0 \\
1.1 \\
1.2 \\
1.5\end{array}$ & $\begin{array}{c}. . \\
0.7-1.5 \\
0.7-2.1 \\
0.7-3.1\end{array}$ \\
\hline \multicolumn{13}{|c|}{ Health risk behavior (overweight, lack of exercise and smoking), sum index } \\
\hline $\begin{array}{l}0 \\
1-3 \\
4-6\end{array}$ & $\begin{array}{l}1.0 \\
0.9 \\
1.1\end{array}$ & $\begin{array}{c}. . \\
0.6-1.4 \\
0.7-2.0\end{array}$ & $\begin{array}{l}1.0 \\
0.9 \\
0.9\end{array}$ & $\begin{array}{c}. . \\
0.6-1.4 \\
0.5-1.5\end{array}$ & $\begin{array}{l}1.0 \\
1.0 \\
1.2\end{array}$ & $\begin{array}{c}. . \\
0.6-1.6 \\
0.7-2.1\end{array}$ & $\begin{array}{l}1.0 \\
0.9 \\
1.0\end{array}$ & $\begin{array}{c}. . \\
0.6-1.4 \\
0.6-1.7\end{array}$ & $\begin{array}{l}1.0 \\
1.8 \\
2.8\end{array}$ & $\begin{array}{c}. . \\
1.0-3.3 \\
1.5-5.4\end{array}$ & $\begin{array}{l}1.0 \\
1.7 \\
2.8\end{array}$ & $\begin{array}{c}. . \\
1.0-3.1 \\
1.4-5.4\end{array}$ \\
\hline \multicolumn{13}{|l|}{ Sleeping disturbance } \\
\hline $\begin{array}{l}\text { No } \\
\text { Mild } \\
\text { Severe }\end{array}$ & $\begin{array}{l}1.0 \\
1.2 \\
1.7\end{array}$ & $\begin{array}{c}\ddot{*} \\
0.9-1.7 \\
0.9-3.1\end{array}$ & $\begin{array}{l}1.0 \\
1.0 \\
0.9\end{array}$ & $\begin{array}{c}\ddot{*} \\
0.7-1.5 \\
0.5-1.7\end{array}$ & $\begin{array}{l}1.0 \\
1.6 \\
3.2\end{array}$ & $\begin{array}{c}. \ddot{ } \\
1.2-2.3 \\
1.9-5.5\end{array}$ & $\begin{array}{l}1.0 \\
1.3 \\
2.3\end{array}$ & $\begin{array}{c}\ddot{*} \\
0.9-1.8 \\
1.3-4.3\end{array}$ & $\begin{array}{l}1.0 \\
2.1 \\
2.5\end{array}$ & $\begin{array}{c}. . \\
1.4-3.2 \\
1.2-5.0\end{array}$ & $\begin{array}{l}1.0 \\
2.0 \\
2.1\end{array}$ & $\begin{array}{c}. . \\
1.3-3.0 \\
1.0-4.6\end{array}$ \\
\hline \multicolumn{13}{|c|}{ Mental distress (being stressed, nervous or tense) } \\
\hline $\begin{array}{l}\text { No } \\
\text { Somewhat } \\
\text { Much or very much }\end{array}$ & $\begin{array}{l}1.0 \\
1.3 \\
1.5\end{array}$ & $\begin{array}{c}. . \\
0.9-1.9 \\
1.0-2.5\end{array}$ & $\begin{array}{l}1.0 \\
1.1 \\
1.4\end{array}$ & $\begin{array}{c}. . \\
0.8-1.6 \\
0.8-2.3\end{array}$ & $\begin{array}{l}1.0 \\
1.8 \\
2.2\end{array}$ & $\begin{array}{c}. . \\
1.2-2.6 \\
1.3-3.7\end{array}$ & $\begin{array}{l}1.0 \\
1.6 \\
1.5\end{array}$ & $\begin{array}{c}. . \\
1.1-2.3 \\
0.8-2.6\end{array}$ & $\begin{array}{l}1.0 \\
1.5 \\
2.1\end{array}$ & $\begin{array}{c}. . \\
1.0-2.2 \\
1.3-3.5\end{array}$ & $\begin{array}{l}1.0 \\
1.2 \\
1.5\end{array}$ & $\begin{array}{c}. . \\
0.8-1.7 \\
0.9-2.5\end{array}$ \\
\hline \multicolumn{13}{|l|}{ Satisfaction with life } \\
\hline $\begin{array}{l}\text { Satisfied } \\
\text { Not satisfied }\end{array}$ & $\begin{array}{l}1.0 \\
1.2\end{array}$ & $\begin{array}{c}. . \\
0.8-1.7\end{array}$ & $\begin{array}{l}1.0 \\
1.0\end{array}$ & $\begin{array}{c}. . \\
0.7-1.5\end{array}$ & $\begin{array}{l}1.0 \\
1.8\end{array}$ & $\begin{array}{c}. . \\
1.2-2.6\end{array}$ & $\begin{array}{l}1.0 \\
1.5\end{array}$ & $\begin{array}{c}. . \\
1.0-2.1\end{array}$ & $\begin{array}{l}1.0 \\
1.1\end{array}$ & $\begin{array}{c}. . \\
0.7-1.7\end{array}$ & $\begin{array}{l}1.0 \\
0.8\end{array}$ & $\begin{array}{c}\ddot{*} \\
0.5-1.3\end{array}$ \\
\hline \multicolumn{13}{|l|}{ Chronic diseases } \\
\hline $\begin{array}{l}\text { No } \\
\text { Yes }\end{array}$ & $\begin{array}{l}1.0 \\
1.7\end{array}$ & $\begin{array}{c}. . \\
1.2-2.4\end{array}$ & $\begin{array}{l}1.0 \\
1.5\end{array}$ & $\begin{array}{c}\ddot{*} \\
1.1-2.2\end{array}$ & $\begin{array}{l}1.0 \\
1.1\end{array}$ & $\begin{array}{c}. \ddot{ } \\
0.7-1.6\end{array}$ & $\begin{array}{l}1.0 \\
0.8\end{array}$ & $\begin{array}{c}\ddot{.} \\
0.6-1.2\end{array}$ & $\begin{array}{l}1.0 \\
1.4\end{array}$ & $\begin{array}{c}. . \\
1.0-2.0\end{array}$ & $\begin{array}{l}1.0 \\
1.1\end{array}$ & $\begin{array}{c}\ddot{.} \\
0.8-1.6\end{array}$ \\
\hline \multicolumn{13}{|c|}{ Pain in other areas (neck, upper extremities, hip or knee) } \\
\hline $\begin{array}{l}\text { No } \\
\text { Yes }\end{array}$ & $\begin{array}{l}1.0 \\
1.8\end{array}$ & $\begin{array}{c}. . \\
1.3-2.5\end{array}$ & $\begin{array}{l}1.0 \\
1.6\end{array}$ & $\begin{array}{c}. . \\
1.2-2.3\end{array}$ & $\begin{array}{l}1.0 \\
1.7\end{array}$ & $\begin{array}{c}. \ddot{ } \\
1.2-2.4\end{array}$ & $\begin{array}{l}1.0 \\
1.4\end{array}$ & $\begin{array}{c}. . \\
0.9-1.9\end{array}$ & $\begin{array}{l}1.0 \\
1.7\end{array}$ & $\begin{array}{c}. \ddot{1}-2.5 \\
\end{array}$ & $\begin{array}{l}1.0 \\
1.2\end{array}$ & $\begin{array}{c}\ddot{*} \\
0.8-1.8\end{array}$ \\
\hline
\end{tabular}

a Models 1a-3a adjusted for gender and age.

${ }^{b}$ Models $1 \mathrm{~b}-3 \mathrm{~b}$ adjusted for all variables listed in the table, and also for gender and age.

muscle fatigue, intradiscal pressure, and microfractures $(7,29)$. Heavy lifting had a modest association with lowback pain, but only among the youngest workers. This finding is consistent with the results of a study among construction workers that showed that manual materials handling was associated with a higher prevalence of low-back pain among younger, but not older (50 years or older) workers (30). Working with awkward trunk postures primarily involves static muscle work, it increases the amount of force needed to accomplish a worktask, and it generates excess mechanical strain on tendons, ligaments, discs, and other soft tissues as well. Hence its effects on the lower back may be related to the decrease in muscle strength that has been shown to begin around the age of 40 years, as well as to poorer tissue recovery (7). This possibility may explain why, in our study, working with awkward postures increased the risk only after 40 years of age. The risks related to lifting or awkward postures not being elevated among the oldest workers may indicate self-selection out of the heaviest loading jobs by the time workers reach the age of 50 years, primarily leaving the workers who are the most resistant to the effects of physical loading in this age group. The healthy worker selection effect is often an unavoidable phenomenon in studies of working populations. It is also possible that the quantity of heavy lifting differed across the age groups (eg, the oldest exposed workers lifting less than the younger workers) and, therefore, diluted the associations. Therefore, we investigated the distribution of the frequency of heavy lifting across the age groups. Although fewer workers aged 50 years or older were exposed to heavy lifting in general, those who lifted did it in fact more than the workers under 40 years of age [a mean of 39 (median 10) times a day versus a mean of 31 (median 5) times a day], whereas workers in the middle-age group most often lifted loads heavier than $25 \mathrm{~kg}$ [a mean of 48 (median 6.5) times a day]. This difference does not further explain the lack of association between lifting and low-back pain.

Our interest in this study was to assess the risk of low-back pain among those who were exposed to 
multiple factors, as is often the reality in industrial populations. The results showed that, among the youngest workers, the risk of low-back pain was increased only when all three exposures were present, whereas, in the middle-age group, even a single physical exposure produced a significant increase in the risk. Being exposed to multiple health risks increased the risk of future lowback pain only among the oldest workers. It is possible that this significant increase in the risk is still an underestimation, in view of the fact that health-based selection is likely to be present in this age group. The joint effects, as presented in table 3 , were higher than the multiplication of the risks of the underlying individual health risk factors (eg, for the youngest workers, a relative risk of 1.92 based on the multiplication being lower than the relative risk produced by the composite variables, 2.4 , a finding which suggests a significant joint effect).

Of the underlying health risk factors, smoking contributed the most to the risk, being highest for the ex-smokers. Our results are consistent with the finding of several cross-sectional and longitudinal populationbased studies, which have shown that current and former smokers have more low-back pain, as well as pain in other areas, than never smokers $(10,12,13,31)$. Cigarette smoking, and nicotine in particular, facilitate degeneration of the intervertebral discs by disturbing disc metabolism and proteoglycan and collagen synthesis, even at the gene expression level (32-34). Smoking may also affect the health of the lumbar spine by inducing atherosclerosis (35).

Some earlier studies have shown a small-to-moderate association between higher body weight or a lack of physical exercise and low-back pain $(1,11,36)$. One possible biomechanical explanation is that both a higher body weight and poorer strength of the supporting spinal muscles lead to chronic overloading of the spine. Obese persons generate higher mechanical moments in the same postures than do people of normal weight; they are also less able to maintain and regain their body stature during and after physical exertion than normal-weight persons, and the inability to regain stature has particularly been associated with an increased risk of low-back pain $(37,38)$. Health behavior may affect low-back pain through other biological mechanisms, such as vascular or inflammatory processes (14). In addition, some psychological factors, such as self-esteem or the self-perception of general well-being, may mediate or modify the associations between health behavior and pain $(39,40)$.

Only a few prospective studies have investigated the possibility of sleep difficulties in pain-free persons predicting future pain, and the results of these studies support a reciprocal causal association $(8,41-43)$. In our study, sleep disturbance predicted the risk of future low-back pain, even when additionally assessed in a subgroup of those who, at the baseline, reported never having experienced low-back pain. As we did not have information on the lifetime history of pain in areas other than the low back, we cannot say whether pain in some other areas before the initiation of this study had preceded sleep disturbance. Nevertheless, sleep disturbance was an independent predictor of low-back pain despite mental distress or aspects of health behavior being in the model, and further adjustment for job strain or education (a crude indicator of socioeconomic status) did not decrease the risk. This finding suggests that sleep problems may independently provoke low-back pain. A causal association is biologically plausible in that sleep deprivation has been shown to produce hyperalgesia (ie, increased sensitivity to pain) in many experimental human and animal studies $(44,45)$. Inflammation may play a role in this process (46). In addition, other mechanisms, such as perturbations in energy metabolism, may lead to musculoskeletal symptoms via the hampering of tissue rebuilding and adaptation (47).

In addition to sleep problems, low satisfaction with life and mental distress increased the risk of low-back pain in the 40- to 49-year-old workers, even when adjusted for each other, and in the presence of chronic disease and pain in other areas. The incidence of low-back pain among the younger workers was not significantly affected by psychological factors or sleep. Our results suggest that the role of mental well-being, such as sleep quality, becomes more important as a determinant of low-back symptoms as age increases.

This study has strengths but also limitations. We used a prospective design in which the exposures were assessed when the workers were free of low-back pain. The participation rates can be considered good, and there was no indication of the survey response at the follow-up being related to the outcome or exposures. Although the assessment of exposures was based on self-reports, most of the questions concerning physical work and psychosocial factors have been validated (21, 24). For physical exposures, the agreement between self-assessed and observed estimations was relatively good, especially among the pain-free workers in this same cohort (21). Since we detected differences in the risk factors and their effects when the analyses were stratified by age, we also tested interactions between age and physical workload and age and health behavior in the whole cohort. The interactions using the product terms did not reach statistical significance when the standard P-value of $\geq 0.05$ was used. Therefore, we cannot rule out the possibility that the age-related differences in this study occurred due to chance. However, our additional calculations using the whole cohort showed that, for a person who had 2 "independent" risk factors [eg, "high age ( $\geq 50$ years)" and "poor health behavior (index 4-6)")] the relative risk for low-back pain would be 1.3. The age-stratified analyses produced a higher risk 
(RR 2.8). In this case, the multiplicative model failed to predict the association, and a significant joint effect can be considered. Problems of nonconvergence did not allow us to fit the log-binomial model with many independent variables and their interactions. A relatively large number of workers had missing values in the questions about chronic diseases. Imputation of "having a chronic disease" or "not having a chronic disease" to those with missing values did not change the main results, except that the effect of physical work somewhat decreased among the two oldest age groups.

Information on symptoms was collected with the validated Nordic questionnaire, which has high repeatability and sensitivity, is widely used, and has been considered as an international standard $(20,48)$. To dichotomize pain outcome, a cut-off of above 7 days of pain is a common criterion with this instrument $(49,50)$. We also used the standard 12-month time-period for the follow-up and for defining the cohort of workers free of low-back pain at baseline. We believe that this is long enough to exclude at least those with frequently recurring symptoms, but also short enough to decrease the probability of workers forgetting their previous symptoms (5). One-third of the workers reported at baseline that they had never had low-back pain. However, the age distribution did not differ between the whole cohort (free of low-back pain for at least 12 months) and the one-third (never had low-back pain); in other words, it seems that age did not predict whether the new episode of low-back pain that occurred during the follow-up was recurrent or new.

The study population was rather heterogeneous, consisting of workers 19-67 years of age, working in physically loading, as well as sedentary, tasks and living in both rural and urban areas. As in many industrial populations, the gender distribution was predominantly male. Therefore, we did not have sufficient power to examine differences between the genders with respect to the incidence of low-back pain or the effects of the risk factors.

In conclusion, our study showed that younger and older workers were affected by slightly different risk factor patterns. The effects of physical workload diminished with age, whereas the role of health behavior, sleep disturbance, and mental distress in the incidence of low-back pain increased. More prospective studies on the single and joint effects of age-specific risk factors for low-back pain are warranted, noting that very large populations are needed to permit these analyses. Meanwhile, our results support the possible value of health promotion and stress management as a part of prevention programs concerning low-back pain at work, in addition to the more-traditional occupational health and safety measures. Aging workers may benefit particularly from such an integrated approach.

\section{Acknowledgments}

This paper is dedicated to the memory of a dearly missed colleague, Rami Martikainen, MSc (1968-2007).

\section{References}

1. Burton AK, Balague F, Cardon G, Eriksen HR, Henrotin Y, Lahad A, et al. How to prevent low back pain. Best Pract Res Clin Rheumatol. 2005;19(4):541-55.

2. Punnett L, Pruss-Utun A, Nelson DI, Fingerhut MA, Leigh J, Tak S, et al. Estimating the global burden of low back pain attributable to combined occupational exposures. Am J Ind Med. 2005;48(6):459-69.

3. Riihimäki H, Viikari-Juntura E, Moneta G, Kuha J, Videman $\mathrm{T}$, Tola S. Incidence of sciatic pain among men in machine operating, dynamic physical work, and sedentary work: a three-year follow-up. Spine. 1994;19(2):138-42.

4. Hestbaek L, Leboeuf-Yde C, Kyvik KO, Manniche C. The course of low back pain from adolescence to adulthood: eightyear follow-up of 9600 twins. Spine. 2006;31(4):468-72.

5. Miranda H, Gold JE, Gore R, Punnett L. Recall of prior musculoskeletal pain. Scand J Work Environ Health. 2006;32(4):294-9.

6. Lötters F, Burdorf A, Kuiper J, Miedema H. Model for the work-relatedness of low-back pain. Scand J Work Environ Health. 2003;29(6):431-40.

7. Hartvigsen J, Lings S, Leboeuf-Yde C, Bakketeig, L. Psychosocial factors at work in relation to low back pain and consequences of low back pain; a systematic, critical review of prospective cohort studies. Occup Environ Med. 2004;61(1):e2.

8. Clays E, De Bacquer D, Leynen F, Kornitzer M, Kittel F, De Backer G. The impact of psychosocial factors on low back pain: longitudinal results from the Belstress study. Spine. 2007;32(2):262-8.

9. Leino PI. Does leisure time physical activity prevent low back disorders?: a prospective study of metal industry employees. Spine. 1993;18(7):863-71.

10. Leboeuf-Yde C. Smoking and low back pain: a systematic literature review of 41 journal articles reporting 47 epidemiologic studies. Spine. 1999;24(14):1463-70.

11. Leboeuf-Yde C. Body weight and low back pain: a systematic literature review of 56 journal articles reporting on 65 epidemiologic studies. Spine. 2000;25(5):226-37.

12. Hestbaek L, Leboeuf-Yde C, Kyvik KO. Are lifestyle-factors in adolescence predictors for adult low back pain?: a crosssectional and prospective study of young twins. BMC Musculoskelet Disord. 2006;7:27.

13. John U, Hanke M, Meyer C, Volzke H, Baumeister SE, Alte D. Tobacco smoking in relation to pain in a national general population survey. Prev Med. 2006;43(6):477-81.

14. Shiri R, Karppinen J, Leino-Arjas P, Solovieva S, Varonen H, Kalso E, et al. Cardiovascular and lifestyle risk factors in lumbar radicular pain or clinically defined sciatica: a systematic review. Eur Spine J. 2007;16(12):2043-54.

15. Ketola R, Toivonen R, Rauas S, Viikari-Juntura E. Interventiotutkimus hienopaperikoneella: fyysiset kuormitustekijät ja ryhmien toiminta [An intervention study in a fine paper production line: physical work load and functioning of the teams; in Finnish with English summary]. Työ ja Ihminen 
2000;3:286-297.

16. John U, Hanke M, Rumpf HJ, Thyrian JR. Smoking status, cigarettes per day, and their relationship to overweight and obesity among former and current smokers in a national adult general population sample. Int J Obes (Lond). 2005;29(10):1289-94.

17. Wilson DB, Smith BN, Speizer IS, Bean MK, Mitchell KS, Uguy LS, et al. Differences in food intake and exercise by smoking status in adolescents. Prev Med. 2005;40(6):872-9.

18. Meng L, Maskarinec G, Lee J, Kolonel LN. Lifestyle factors and chronic diseases: application of a composite risk index. Prev Med. 1999;29(4):296-304.

19. Dragano N, Verde PE, Siegrist J. Organisational downsizing and work stress: testing synergistic health effects in employed men and women. J Epidemiol Community Health. 2005;59(8):694-9.

20. Kuorinka I, Jonsson B, Kilbom Å, Vinterberg H, Biering-Sörensen F, Andersson G, et al. Standardised Nordic questionnaires for the analysis of musculoskeletal symptoms. Appl Ergon. 1987;18(3):233-7.

21. Viikari-Juntura E, Rauas S, Martikainen R, Kuosma E, Riihimäki H, Takala E-P, et al. Validity of self-reported physical work load in epidemiologic studies on musculoskeletal disorders. Scand J Work Environ Health. 1996;22(4):251-9.

22. Elo A-L, Leppänen A, Lindström K, Ropponen T. Occupational Stress Questionnaire: user's instructions. Helsinki: Finnish Institute of Occupational Health; 1992. Reviews 19.

23. Partinen M, Gislason T. Basic Nordic Sleep Questionnaire (BNSQ): a quantitated measure of subjective sleep complaints. J Sleep Res. 1995;4(S1):150-5.

24. Elo A-L, Leppänen A, Jahkola A. Validity of a single-item measure of stress symptoms. Scand J Work Environ Health. 2003;29(6):444-51.

25. Spiegelman D, Hertzmark E. Easy SAS calculations for risk or prevalence ratios and differences. Am J Epidemiol. 2005;162(3):199-200.

26. Manninen $P$, Riihimäki $H$, Heliövaara $M$. Incidence and risk factors of low-back pain in middle-aged farmers. Occup Med (Lond). 1995;45(3):141-6.

27. Maul I, Läubli T, Klipstein A, Krueger H. Course of low back pain among nurses: a longitudinal study across eight years. Occup Environ Med. 2003;60(7):497-503.

28. Van Nieuwenhuyse A, Somville PR, Crombez G, Burdorf A, Verbeke G, Johannik K, et al. The role of physical workload and pain related fear in the development of low back pain in young workers: evidence from the BelCoBack Study; results after one year of follow up. Occup Environ Med. 2006;63(1):45-52.

29. Waters T, Rauche C, Genaidy A, Rashed T. A new framework for evaluating potential risk of back disorders due to whole body vibration and repeated mechanical shock. Ergonomics. 2007;50(3):379-95.

30. Holmström EB, Lindell J, Moritz U. Low back and neck/shoulder pain in construction workers: occupational workload and psychosocial risk factors: part 1: relationship to low back pain. Spine. 1992;17(6):663-71.

31. Palmer KT, Syddall H, Cooper C, Coggon D. Smoking and musculoskeletal disorders: findings from a British national survey. Ann Rheum Dis. 2003;62(1):33-6.

32. Iwahashi M, Matsuzaki H, Tokuhashi Y, Wakabayashi K, Uematsu Y. Mechanism of intervertebral disc degeneration caused by nicotine in rabbits to explicate intervertebral disc disorders caused by smoking. Spine. 2002;27(13):1396-401.

33. Akmal M, Kesani A, Anand B, Singh A, Wiseman M, Goodship A. Effect of nicotine on spinal disc cells: a cellular mecha- nism for disc degeneration. Spine. 2004;29(5):568-75.

34. Uei H, Matsuzaki H, Oda H, Nakajima S, Tokuhashi Y, Esumi M. Gene expression changes in an early stage of intervertebral disc degeneration induced by passive cigarette smoking. Spine. 2006;31(5):510-4.

35. Kurunlahti M, Tervonen O, Vanharanta H, Ilkko E, Suramo I. Association of atherosclerosis with low back pain and the degree of disc degeneration. Spine. 1999;24(20):2080-4.

36. Shiri R, Solovieva S, Husgafvel-Pursiainen K, Taimela S, Saarikoski LA, Huupponen R, et al. The association between obesity and the prevalence of low back pain in young adults: the cardiovascular risk in young Finns study. Am J Epidemiol. 2008;167(9):1110-9.

37. Rodacki CL, Fowler NE, Rodacki AL, Birch K. Stature loss and recovery in pregnant women with and without low back pain. Arch Phys Med Rehabil. 2003;84(4):507-12.

38. Rodacki AL, Fowler NE, Provensi CL, Rodacki Cde L, Dezan $\mathrm{VH}$. Body mass as a factor in stature change. Clin Biomech (Bristol, Avon). 2005;20(8):799-805.

39. Peltonen M, Lindroos AK, Torgerson JS. Musculoskeletal pain in the obese: a comparison with a general population and longterm changes after conventional and surgical obesity treatment. Pain. 2003;104(3):549-57.

40. Nagyova I, Stewart RE, Macejova Z, van Dijk JP, van den Heuvel WJ. The impact of pain on psychological well-being in rheumatoid arthritis: the mediating effects of self-esteem and adjustment to disease. Patient Educ Couns. 2005;58(1):55-62

41. Haig AJ, Tong HC, Yamakawa KS, Parres C, Quint DJ, Chiodo A, et al. Predictors of pain and function in persons with spinal stenosis, LBP, and no back pain. Spine. 2006;31(25):2950-7.

42. Kaila-Kangas L, Kivimäki M, Härmä M, Riihimäki H, Luukkonen R, Kirjonen J, et al. Sleep disturbances as predictors of hospitalization for back disorders-a 28-year follow-up of industrial employees. Spine. 2006;31(1):51-6.

43. Morphy H, Dunn KM, Lewis M, Boardman HF, Croft PR. Epidemiology of insomnia: a longitudinal study in a UK population. Sleep. 2007;30(3):274-80.

44. Lautenbacher S, Kundermann B, Krieg JC. Sleep deprivation and pain perception. Sleep. Med Rev 2006;10(5):357-69.

45. Roehrs T, Hyde M, Blaisdell B, Greenwald M, Roth T. Sleep loss and REM sleep loss are hyperalgesic. Sleep. 2006;29(2):145-51.

46. Irwin MR, Wang M, Campomayor CO, Collado-Hidalgo A, Cole S. Sleep deprivation and activation of morning levels of cellular and genomic markers of inflammation. Arch Intern Med. 2006;166(16):1756-62.

47. Schmid SM, Hallschmid M, Jauch-Chara K, Bandorf N, Born J, Schultes B. Sleep loss alters basal metabolic hormone secretion and modulates the dynamic counterregulatory response to hypoglycemia. J Clin Endocrinol Metab. 2007;92(8):304451.

48. Palmer K, Smith G, Kellingray S, Cooper C. Repeatability and validity of an upper limb and neck discomfort questionnaire: the utility of the standardized Nordic Questionnaire. Occup Med (Lond). 1999;49(3):171-5.

49. Miranda H, Viikari-Juntura E, Martikainen R, Takala EP, Riihimäki H. Individual factors, occupational loading, and physical exercise as predictors of sciatic pain. Spine. 2002;27(10):1102-9.

50. Schenk P, Laeubli T, Klipstein A. Validity of pressure pain thresholds in female workers with and without recurrent low back pain. Eur Spine J. 2007;16(2):267-75.

Received for publication: 5 February 2008 